\title{
Incubation Period in Coronavirus Disease 2019 (COVID-19): A Literature Review
}

\author{
Author Details
}

Ishan Poudel (Corresponding Author)

Affiliation: Woodhull Medical and Mental Health Center, Brooklyn, NY, USA

Email: ishanpoudel@gmail.com

ORCID iD: https://orcid.org/0000-0001-8939-3047

Ankur Sah Swarnakar

Affiliation: Saint Elizabeths Hospital, Washington, DC, USA

Email:sahswarnakarankur@gmail.com

ORCID iD: https://orcid.org/0000-0001-8171-9022

\begin{abstract}
Coronavirus Disease 2019 (COVID-19) is a respiratory illness caused by Severe Acute Respiratory Syndrome Coronavirus 2 (SARS-CoV-2). It is considered to be first reported from Wuhan, Hubei Province, China in December 2019. As of present, there are over 3.7 million identified cases worldwide and more than 259,000 deaths have been reported. This disease, its incubation period, course, complications, and the basis of spread remains a potential question due to variation in the pattern of spread around the globe and relatively fewer number of largescale studies at present. This literature review aims to study the available data on its spread and incubation period. A literature search using PubMed with regular keywords 'coronavirus' and 'COVID-19', and Medical Subject Headings (MeSH) search for their etiology and pathogenicity was done with the search builder. The literature search revealed 26,689 studies among which 14 studies were selected for review. Studies were selected after the application of inclusion criteria and exclusion criteria with the removal of duplicates, and careful review for the outcome of interest 'incubation period'. Among the 14 studies selected for review, there were eight review articles, five case reports, and one comparative study. The current literature review concludes that the mean incubation period for most of the literature falls between five days to 12 days with minimum reported time from known exposure to the onset of a symptom being one day and the maximum reported time from exposure to the onset of a symptom being 18 days.
\end{abstract}

\section{Keywords}

coronavirus, COVID-19, coronavirus etiology, coronavirus pathogenicity

\section{Introduction}

Coronavirus Disease 2019 (COVID-19), a respiratory illness caused by Severe Acute Respiratory Syndrome Coronavirus 2 (SARS-CoV-2) is considered to be first reported from Wuhan, China in December 2019 (1). This infection has taken the face of a global pandemic as of present with over 3.7 million identified cases worldwide and more than 259,000 deaths reported due to its infection or complications (2). With multiple reports and articles published in a relatively short duration, this disease, its complications and the basis of spread remains a potential question due to variation in the pattern of spread around the globe. This literature review aims to study the available data on its spread and incubation period. 


\section{Methods}

A literature search using PubMed with both regular and Medical Subjects Headings (MeSH) keywords revealed 26,689 studies. Ninety-one studies were selected after the application of inclusion/exclusion criteria in the following order.

Inclusion Criteria:

1. Articles published on or after Feb1, 2020

2. Human subjects

3. Papers published in the English language

4. Free full text available online

5. Study types included were case reports, review articles, clinical study, case-control study, and randomized control trials.

Exclusion Criteria

1. Exclusive animal studies

2. Literature in languages other than English

\section{Results}

Table 1. Number of articles in regular keyword searches. Results are obtained after the application of respective inclusion/exclusion in order from top to bottom of table.

\begin{tabular}{|l|l|}
\hline Regular keywords & Number of articles obtained \\
\hline Coronavirus & 16385 \\
\hline Total records & \\
\hline Inclusion/exclusion & 1701 \\
\hline Published on or after Feb 1,2020 & 455 \\
\hline Humans & 401 \\
\hline English language literature & 184 \\
\hline Free full text online & 36 \\
\hline Study type & \\
\hline COVID-19 & 2182 \\
\hline Total records & \\
\hline Inclusion/exclusion & 2136 \\
\hline Published on or after Feb 1,2020 & 439 \\
\hline Humans & 387 \\
\hline English language literature & 179 \\
\hline Free full text online & 36 \\
\hline Study type &
\end{tabular}


Table 2. Number of articles in the MeSH keyword searches. Results are obtained after the application of inclusion/exclusion in in order from top to bottom of table.

\begin{tabular}{|l|l|}
\hline $\begin{array}{l}\text { MeSH Keywords } \\
\text { Coronavirus } \\
\text { Subheading-Etiology }\end{array}$ \\
\hline Total records & 6425 \\
\hline Inclusion/exclusion & \\
\hline Published on or after Feb 1, 2020 & 76 \\
\hline Humans & 72 \\
\hline English language literature & 71 \\
\hline Free full text online & 41 \\
\hline Study type & 11 \\
\hline $\begin{array}{l}\text { Coronavirus } \\
\text { Subheading- Pathogenicity }\end{array}$ & \\
\hline Total records & 1697 \\
\hline Inclusion/exclusion & \\
\hline Published on or after Feb 1,2020 & 77 \\
\hline Humans & 77 \\
\hline English language literature & 69 \\
\hline Free full text online & 29 \\
\hline Study type & 8 \\
\hline
\end{tabular}

After the removal of duplicates, 36 articles were obtained. Among the 36 selected articles, there were 18 case reports, 16 review articles, one clinical study, and one comparative study. A complete review excluded 22 articles due to the lack of an outcome of interest incubation period'.

Finally, a review of 14 publications in PubMed with free full-text available online was done which included:

- Eight review articles (3-10).

- Five case reports (11-15).

- One comparative study (16). 
Figure 1. Flow chart depicting the complete process of literature search.

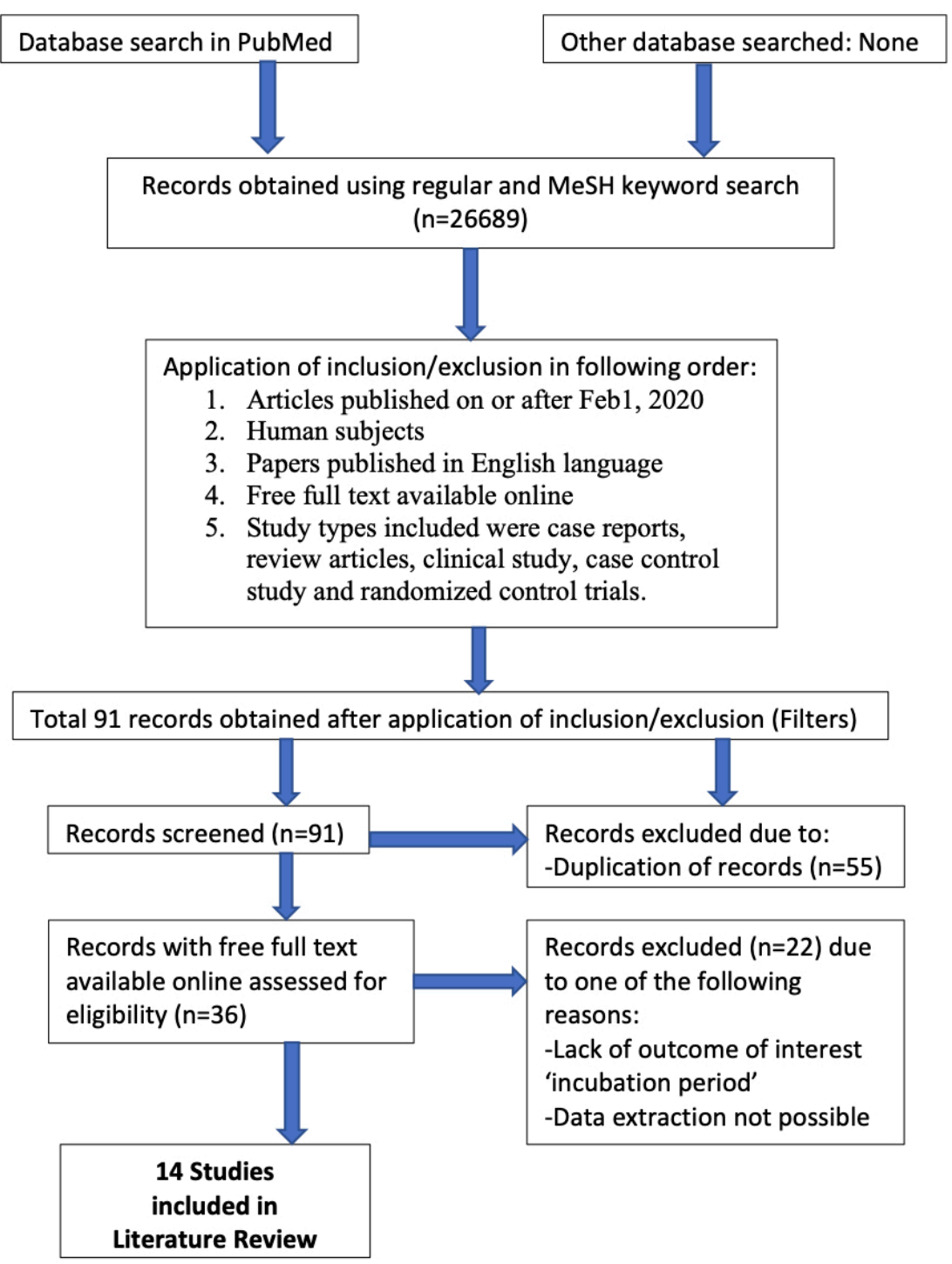




\section{Discussion}

The analysis is aimed to know the reported incubation period of SARS-CoV-2 infection among the 14 reviewed literature. Three of the case reports included in the review reported the time from diagnosis to onset of symptoms that ranged from one day to eight days.

Table 3. Summary of some of the articles with the incubation period reported from the selected data in the literature review.

\begin{tabular}{|l|l|l|}
\hline Author/Date & Study design & $\begin{array}{l}\text { Incubation } \\
\text { period }\end{array}$ \\
\hline $\begin{array}{l}\text { Singhal, Mar } \\
2020(4)\end{array}$ & review & $\begin{array}{l}\text { range of 2-14 } \\
\text { days (median } \\
\text { 5days) }\end{array}$ \\
\hline $\begin{array}{l}\text { Lake, } \\
\text { Mar 2020 (5) }\end{array}$ & review & $\begin{array}{l}\text { range of 9.2- } \\
18 \text { days (mean } \\
\text { 5.2 days) }\end{array}$ \\
\hline $\begin{array}{l}\text { Okata et al. } \\
\text { Feb 2020 (12) }\end{array}$ & case reports & $\begin{array}{l}\text { mean of 6.4 } \\
\text { days }\end{array}$ \\
\hline $\begin{array}{l}\text { Lin et al. Feb } \\
2020(15)\end{array}$ & case reports & $\begin{array}{l}\text { generally, 3-7 } \\
\text { days (no } \\
\text { longer than 14 } \\
\text { days) }\end{array}$ \\
\hline
\end{tabular}

Due to the difference in the capacity of screening methods among the countries mentioned in the articles and variation in contact tracing, future works of literature still have scope to explore much more regarding the incubation period. Among the reviewed literature, the minimum time from known exposure to onset of symptom was one day and the maximum known time was 18 days. However, most of the articles reported their mean to range between five to 12 days.

\section{Conclusion}

The objective of this study is to review the incubation period of COVID-19 infection among recent literature. The current literature review concluded that among the literature reviewed the minimum time from known exposure to onset of symptom was one day and the maximum known time was 18 days with a mean of most of the literature falling between five days to 12 days. However, there remains a broad horizon to explore until the pandemic comes to a complete end with furthermore evaluation. 


\section{References}

1. Gorbalenya AE, Baker SC, Baric RS, de Groot RJ, Drosten C, Gulyaeva AA, et al. The species Severe acute respiratory syndrome-related coronavirus: classifying 2019-nCoV and naming it SARS-CoV-2. Nat Microbiol. 2020 Apr 2;5(4):536-44.

https://doi.org/10.1038/s41564-020-0695-Z

2. World Health Organization (WHO), Coronavirus disease 2019 (COVID-19) Situation Report - 109 [Internet]. 2020 [cited 2020 May 9]. Available from:

https://www.who.int/emergencies/diseases/novel-coronavirus-2019/situation-reports\#

3. Adhikari SP, Meng S, Wu Y-J, Mao Y-P, Ye R-X, Wang Q-Z, et al. Epidemiology, causes, clinical manifestation and diagnosis, prevention and control of coronavirus disease (COVID-19) during the early outbreak period: a scoping review. Infect Dis Poverty. 2020 Dec 17;9(1):29.

http://doi.org/10.1186/s40249-020-00646-X

4. Singhal T. A Review of Coronavirus Disease-2019 (COVID-19). Indian J Pediatr. 2020 Apr 13;87(4):281-6.

https://doi.org/10.1007/s12098-020-03263-6

5. Lake MA. What we know so far: COVID-19 current clinical knowledge and research. Clin Med (Northfield Il). 2020 Mar;20(2):124-7.

https://doi.org/10.7861/clinmed.2019-coron

6. Shanmugaraj B, Siriwattananon K, Wangkanont K, Phoolcharoen W. Perspectives on monoclonal antibody therapy as potential therapeutic intervention for Coronavirus disease-19 (COVID-19). Asian Pacific J allergy Immunol. 2020 Mar;38(1):10-8.

https://doi.org/10.12932/AP-200220-0773

7. Peng X, Xu X, Li Y, Cheng L, Zhou X, Ren B. Transmission routes of 2019-nCoV and controls in dental practice. Int J Oral Sci. 2020 Dec 3;12(1):9.

https://doi.org/10.1038/s41368-020-0075-9

8. Prompetchara E, Ketloy C, Palaga T. Immune responses in COVID-19 and potential vaccines: Lessons learned from SARS and MERS epidemic. Asian Pacific J allergy Immunol. 2020 Mar;38(1):1-9.

https://doi.org/10.12932/AP-200220-0772

9. Li J-Y, You Z, Wang Q, Zhou Z-J, Qiu Y, Luo R, et al. The epidemic of 2019-novelcoronavirus (2019-nCoV) pneumonia and insights for emerging infectious diseases in the future. Microbes Infect. 2020 Mar;22(2):80-5.

https://doi.org/10.1016/j.micinf.2020.02.002

10. Ryu S, Chun BC. An interim review of the epidemiological characteristics of 2019 novel coronavirus. Epidemiol Health. 2020 Feb 6;42:e2020006.

https://doi.org/10.4178/epih.e2020006

11. Park JY, Han MS, Park KU, Kim JY, Choi EH. First Pediatric Case of Coronavirus Disease 2019 in Korea. J Korean Med Sci. 2020;35(11).

https://doi.org/10.3346/jkms.2020.35.e124

12. Okada P, Buathong R, Phuygun S, Thanadachakul T, Parnmen S, Wongboot W, et al. Early transmission patterns of coronavirus disease 2019 (COVID-19) in travellers from Wuhan to Thailand, January 2020. Eurosurveillance. 2020 Feb 27;25(8).

https://doi.org/10.2807/1560-7917.ES.2020.25.8.2000097 
13. Wei J, Xu H, Xiong J, Shen Q, Fan B, Ye C, et al. 2019 Novel Coronavirus (COVID-19) Pneumonia: Serial Computed Tomography Findings. Korean J Radiol. 2020;21(4):501. https://doi.org/10.3348/kjr.2020.0112

14. Bernard Stoecklin S, Rolland P, Silue Y, Mailles A, Campese C, Simondon A, et al. First cases of coronavirus disease 2019 (COVID-19) in France: surveillance, investigations and control measures, January 2020. Eurosurveillance. 2020 Feb 13;25(6).

https://doi.org/10.2807/1560-7917.ES.2020.25.6.2000094

15. Lin X, Gong Z, Xiao Z, Xiong J, Fan B, Liu J. Novel Coronavirus Pneumonia Outbreak in 2019: Computed Tomographic Findings in Two Cases. Korean J Radiol. 2020;21(3):365.

https://doi.org/10.3348/kjr.2020.0078

16. Xu J, Zhao S, Teng T, Abdalla AE, Zhu W, Xie L, et al. Systematic Comparison of Two Animal-to-Human Transmitted Human Coronaviruses: SARS-CoV-2 and SARS-CoV. Viruses. 2020 Feb 22;12(2):244.

https://doi.org/10.3390/v12020244 